\title{
Intracellular Transport of Albumin through the Secretory Apparatus of Rat Liver Parenchymal Cells. An Immunocytochemical Study
}

\author{
Sadaki Yokota and Dariush H. Fahimi* \\ Department of Anatomy, Yamanashi Medical School, Yamanashi 409-38, \\ Japan and *Department of Anatomy, II Division, University of Heidelberg, \\ Im Neuenheimer Feld 307, D-6900 Heidelberg, 1 Federal Republic of Germany
}

\begin{abstract}
The fine structural localization of albumin in rat liver parenchymal cells was determined by an improved immunocytochemical method and serial sectioning. Albumin in the secretory apparatus of the parenchymal cells was present in segments of the rough endoplasmic reticulum, interrupted with negative segments, in transport vesicles, Golgi saccules, finely anastomosed tubules and vesicles on the trans side of the Golgi complex, and in secretion granules. Horizontally sectioned Golgi saccules contained lipoprotein particles on one side and albumin on the other side. After transport, the vesicles that contained albumin fused with the so-called rigid lamellae on the trans-side of the Golgi complex. Ultrathin serial sections revealed no true structural continuity between the endoplasmic reticulum and the cis-aspect of the Golgi complex. We concluded that secretory proteins are transported from the endoplasmic reticulum to the Golgi complex by transport vesicles that bud from the endoplasmic reticulum and fuse with the Golgi saccules. These vesicles fuse regularly with the Golgi saccules on the cis-side and occasionally with tubular elements on the trans-aspect that may belong to the so-called GERL.
\end{abstract}

Secretory proteins are synthesized on membrane-bound polyribosomes and are transported to the Golgi complex where they are condensed and packed into the secretory granules (25-28). The intracellular pathway in the liver of the secretory proteins, mainly albumin, has been the subject of intense research. Albumin is synthesized primarily on membrane-bound polyribosomes $(15,35,42,44,47,51)$ with a pre-piece N-terminal extension (52) and is segregated as the precursor form, pro-albumin, in the lumen of the endoplasmic reticulum (ER) $(9,29,50)$. Pro-albumin is transported to the Golgi apparatus $(16,17,44)$, where it then is packed in the secretion granules. Late in this secretory process, pro-albumin is converted to serum type of albumin by proteolysis $(22,30)$.

Current theories on the exact route taken by secretory products through the Golgi apparatus $(10,11,36,49,54)$ presume that transport vesicles that are to

Abbreviations used: ER, endoplasmic reticulum; rER, rough surfaced ER; sER, smooth surfaced ER. 
contain the secretory products bud from the transitional element of the ER, enter the Golgi complex on the cis side and cross each cisterna, eventually reaching the condensing granules on the trans side $(10,11,36,49,54)$. Although bypassage of Golgi saccules and direct transport to the trans side has been suggested (33), there is little published morphological evidence to support this possibility. Immunocytochemical localization of albumin has provided detailed information on the intracellular pathway of secretory proteins in the hepatocytes $(5,24,53,56)$.

Of the various immunoelectron microscopy techniques used to determine the intracellular localization of antigens, the gold labeling of ultrathin sections is probably the most elegant approach $(5,53)$ but it lacks the sensitivity provided by the intensification of peroxidase-labelled antibodies that is the main advantage of the pre-embedding technique (56). This latter technique, however, has the disadvantage of limited penetration of the labeled antibodies into the sections. Although use of detergents facilitates penetration, there usually is structural damage to delicate organelles such as the Golgi complex. We have developed a modified technique that uses very mild fixation and a mild detergent (Triton WR 1339) to determine localization of albumin and have used it to investigate in detail the transport of albumin from the ER to the Golgi apparatus.

\section{MATERIALS AND METHODS}

Purification and immunization procedures for rat serum albumin have been described elsewhere (56). Fab fragments from an IgG fraction were prepared by the method of Porter (45). Monospecific Fab fragments of anti-rat albumin antibody that had been obtained by affinity chromatography on albumin-coupled Sepharose 6B were conjugated with horseradish peroxidase (Grade III, Boeringer Mannheim, Germany) after which purified further by gel-filtration (1). The conjugate was chromatographed on Ultrogel AcA 34 (LKB, Bromma, Sweden), and the resulting shoulder fractions between the first and second peaks were used for the immunocytochemical staining.

Wistar albino rats (180-200 g) that had fasted for $18 \mathrm{~h}$ were killed and their livers excised. Livers were perfused through the portal vein with physiological saline for $30 \mathrm{sec}$ then with fixative for $5 \mathrm{~min}$ at room temperature. Excess fixative was washed away by further perfusion with physiological saline. The fixative used was composed of $4 \%$ formaldehyde, $0.02 \%$ glutaraldehyde, $4 \%$ polyvinylpyrrolidone, $0.1 \% \mathrm{NaN}_{3}, 0.01 \% \mathrm{CaCl}_{2}$, and $0.15 \mathrm{M}$ cacodylate buffer, pH 7.4.

The fixed livers were cut into tissue sections ( $50 \mu \mathrm{m}$ thick) with a Vibratome (Oxford Labs, Calif. USA), the sections treated first with $0.1 \mathrm{M}$ lysine for $30 \mathrm{~min}$ then with $0.01-0.02 \%$ Triton WR 1339 in PBS for $15 \mathrm{~min}$. After being washed, the sections were incubated for $4 \mathrm{~h}$ at $20^{\circ} \mathrm{C}$ with constant shaking in $0.2 \mathrm{M}$ sucrose solution that contained peroxidaselabelled specific Fab $(60 \mu \mathrm{g} / \mathrm{ml})$ or peroxidase-labelled nonspecific Fab $(100 \mu \mathrm{g} / \mathrm{ml})$. After incubation, the tissue sections were rinsed three times with $0.15 \mathrm{M}$ cacodylate buffer, $\mathrm{pH} 7.4$, after which they were fixed in $2 \%$ glutaraldehyde and incubated for $15 \mathrm{~min}$ at $24^{\circ} \mathrm{C}$ in diaminobenzidine (DAB) $-\mathrm{H}_{2} \mathrm{O}_{2}$ medium for peroxidase (19). These sections were postosmicated for $60 \mathrm{~min}$, then dehydrated and embedded in Epon.

Ultrathin sections were cut with a diamond knife on an LKB ultrotome then mounted on copper grids. Serial ultrathin sections were cut in the same way and mounted on Formvar membrane-coated copper grids that had a single hole. These sections were stained with lead citrate and examined in a Philips EM301 electron microscope at $80 \mathrm{kv}$. 


\section{RESULTS}

Light microscopy showed that albumin was present in all the parenchymal cells of rat liver, as reported previously (56), and there was no staining gradient from the center to the periphery of the hepatic lobule. Two types of staining for albumin were recognizable, one was intense and discrete granular, the other weak and diffuse (Fig. 1a). Large reaction deposits of the former type mainly were present in the cytoplasm around the bile canaliculi, and smaller deposits were present on the sinusoidal side. The latter type of deposit was present in nuclear envelope and in lamellar masses, scattered throughout the cytoplasm, which seemed to be the ER (Fig. 1b).

Electron microscopy showed dense reaction products localized in the cisterna of the smooth and rough endoplasmic reticula (ER) as well as in the nuclear envelope, Golgi complex and in secretion and lysosome-like granules (Fig. 1c). The nuclei, mitochondria and peroxisomes were consistently negative. There was no positive staining in those organelles in control sections incubated in peroxidase-labeled nonspecific Fab.

In the rough ER (rER), the membrane and the cisterna were stained, but the ribosomes were not (Fig. 2a and b). Staining was localized in the terminal dilatations without ribosomes and in some segments, that were interspersed with negative ones (Fig. 2b). A small number of smooth vesicles that showed positive reactions were scattered throughout the cytoplasm together with negative vesicles. The vesicles containing lipoprotein particles were always negative for albumin as previously reported (56), or the albumin-containing vesicles had no lipoprotein particles (Fig. 2b). On the trans side of the Golgi complex, however, albumin and lipoprotein particles were localized in the same vacuoles, in which the lipoprotein particles were seen in negative relief in the heavily stained matrix (Figs. 3 and 4).

On the cytoplasmic surface of the Golgi saccules and the vacuoles there were many small protrusions that suggested the fusion or fission of transport vesicles with these organelles (Fig. 3). Close to the cis side the reaction product was frequently present in the smooth ER, which was directly interconnected with the rER and was constricted focally forming albumin positive vesicles (Fig. 4a). On the cytoplasmic surfaces of these vesicles, there was a frequent fuzzy coat that was moderately stained (Fig. 3a, $4 c)$. Only rarely was this coat seen on the surfaces of solitary vesicles that stained for albumin. The surfaces of budding protrusions and the terminal dilatations of the rER never showed this fuzzy coat if they were positive for albumin. In a grazing section of a Golgi saccule, albumin was present in the same saccule as lipoprotein particles, the albumin being localized in one corner of a saccule and the lipoprotein particles in another (Fig. 4b).

The rigid lamella that forms the innermost annulated cisterna of the Golgi complex frequently showed the stain (Fig. 3b, c). On the trans side of the Golgi apparatus many secretion granules with diameters of $0.2-0.3 \mu \mathrm{m}$ showed heavy staining. Furthermore, in this region small positive vesicles were fused with reaction-negative vesicles that were larger than the positive vesicles in most cases (Fig. 3c), which suggests that albumin is transported through a bypass to the trans elements of the Golgi complex.

Secretion granules similar to those located on the trans side of the Golgi complex were present in the cytoplasm near by the plasma membrane of the sinusoidal surface but not of the lateral or bile canalicular surface (Fig. 5e). Some secretion granules were open toward the out side of the cell and discharged their contents into the space of 


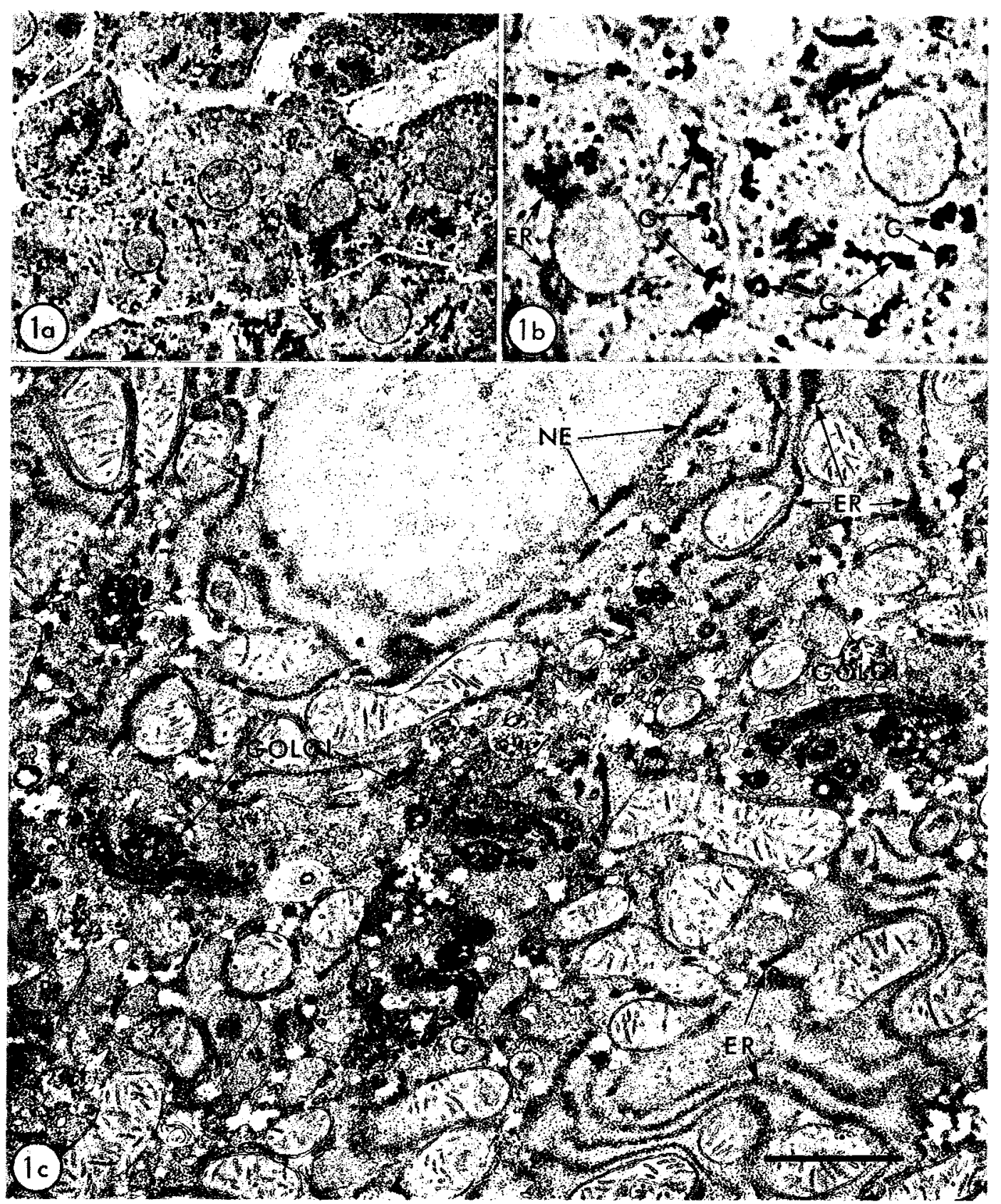




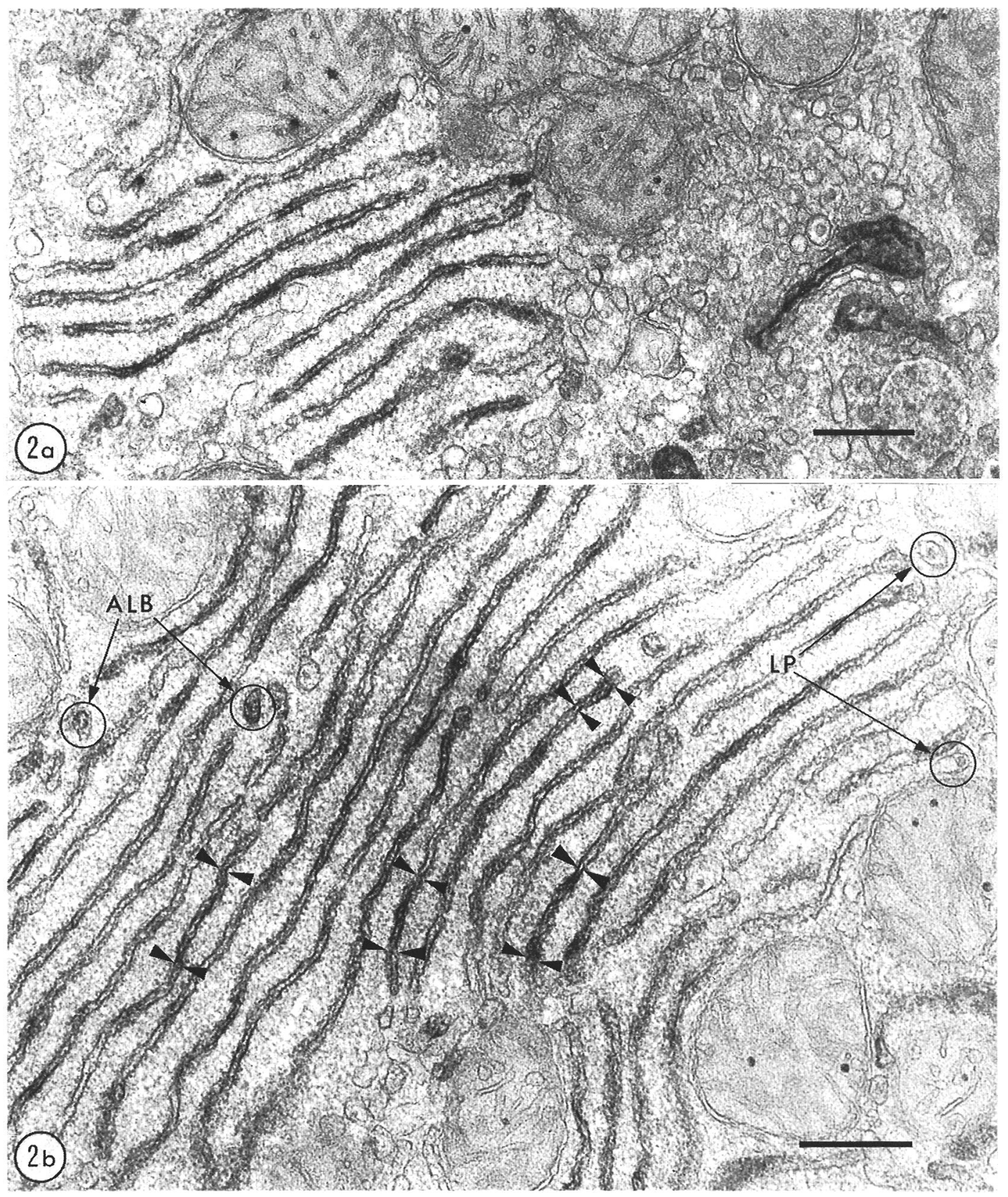




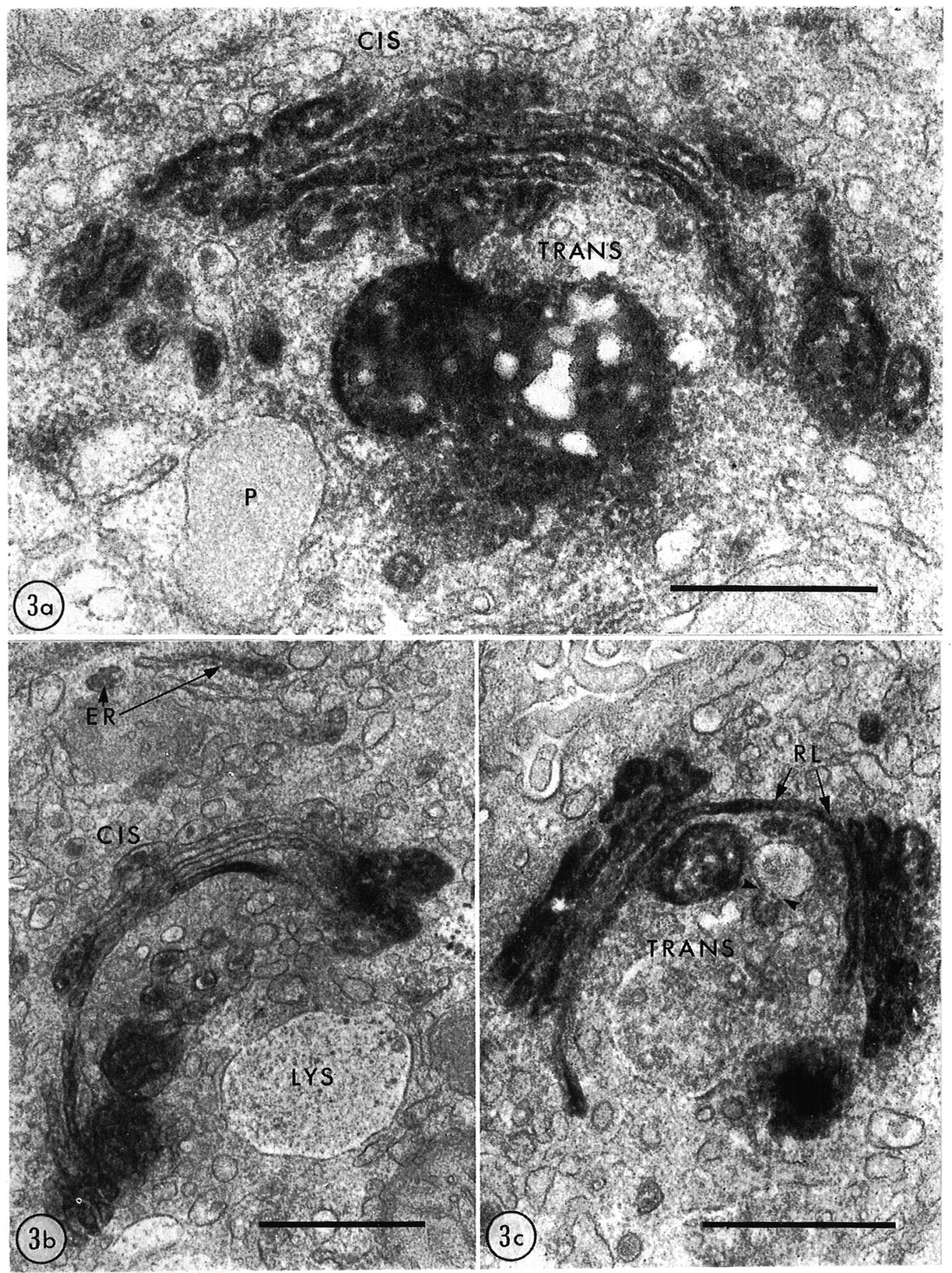




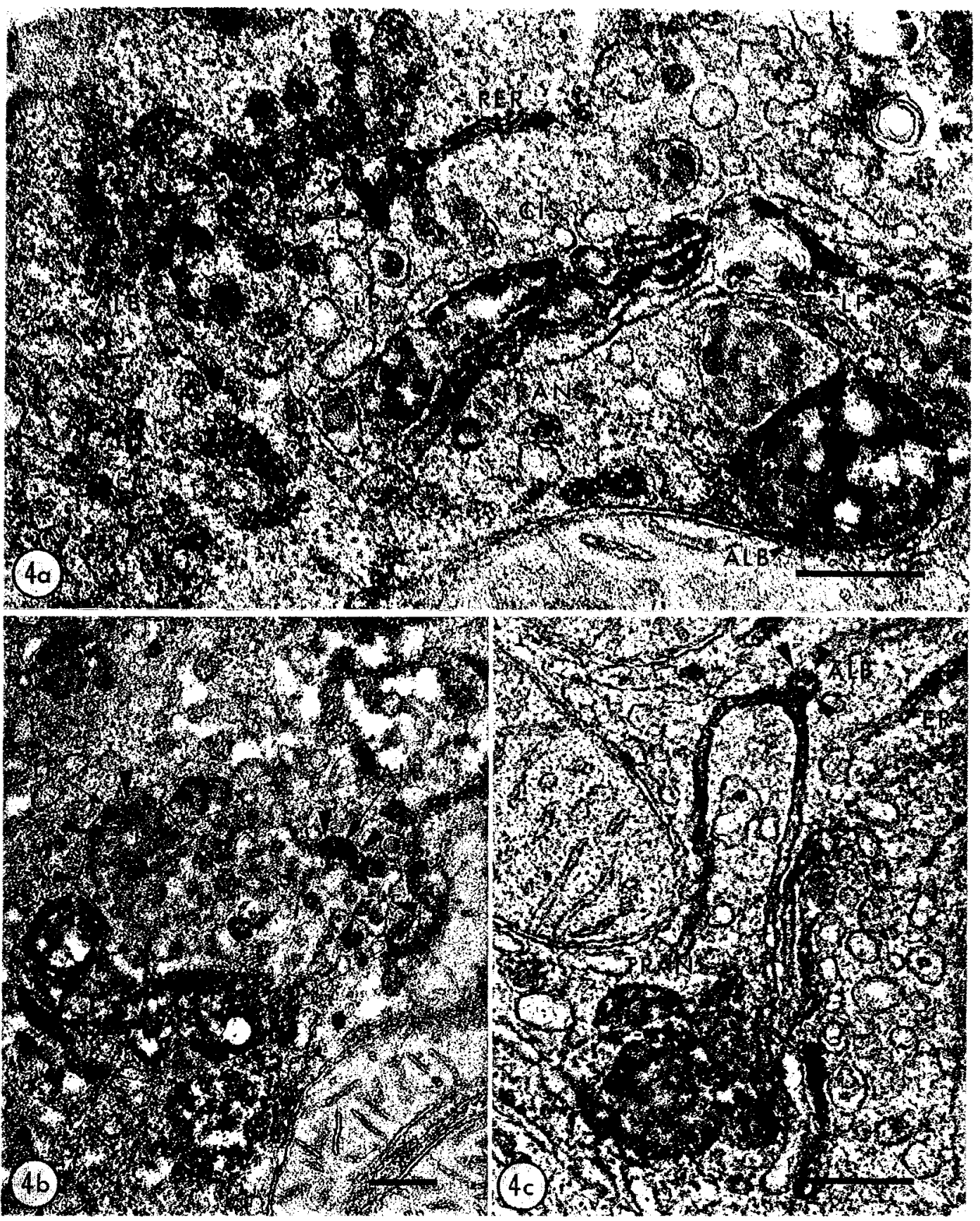




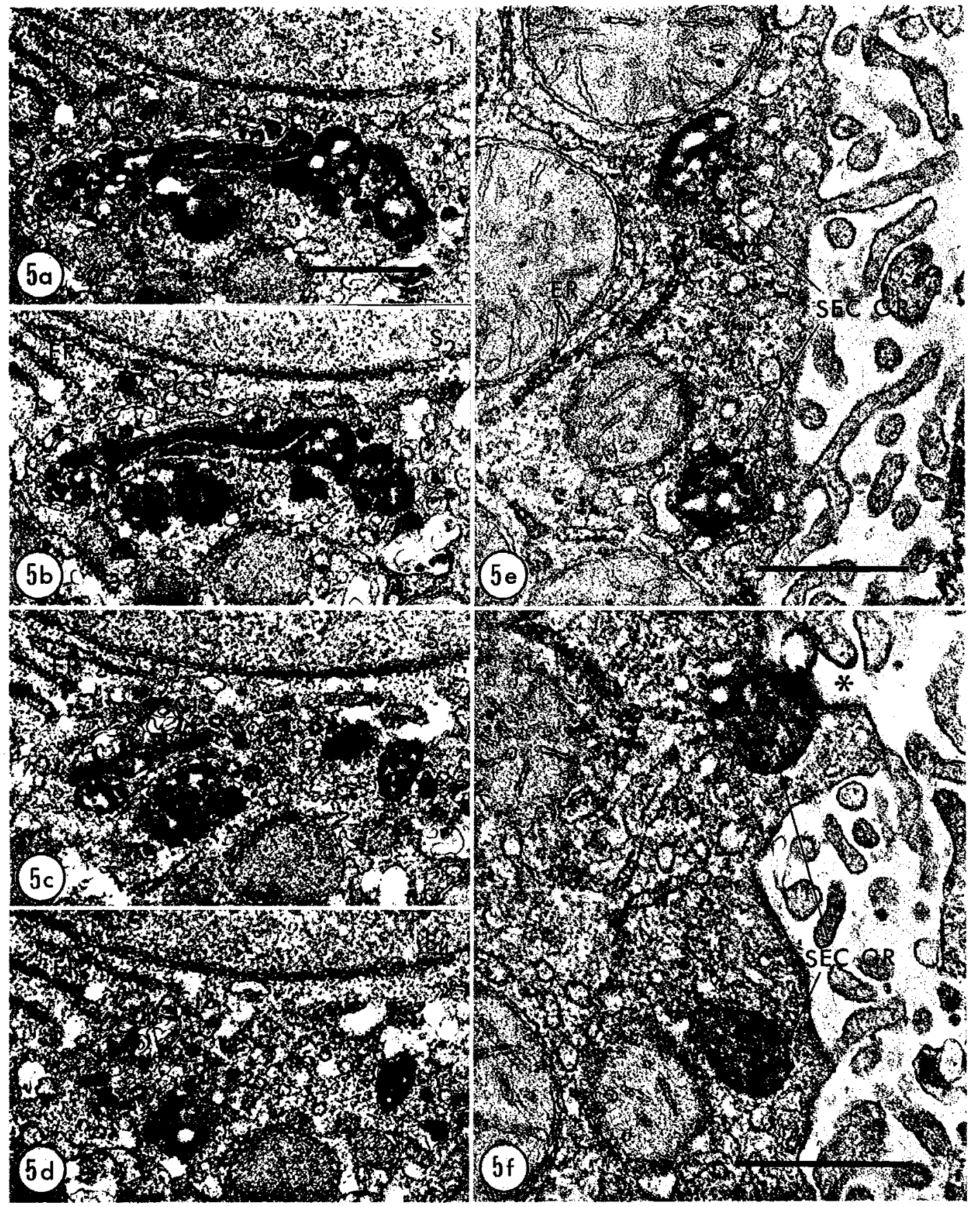


Disse (Fig. 5f).

The Golgi complex and the organelles around it were analyzed by serial sectioning of the immunocytochemically stained tissue. The 5-10 series of these sections from three different experiments were carefully observed. There was no true continuity between the ER and Golgi elements including the saccules, vacuoles and fine network

Figs. 1a, b. Light micrographs of rat liver sections stained immunocytochemically for albumin. 1a. Two types of reaction deposits with different staining intensities; granular, strong staining scattered throughout the cytoplasm of the hepatocytes and diffuse and weak staining that crowds some parts of the cytoplasm. The latter staining also is present in the nuclear envelope. $\times 650.1 \mathrm{~b}$. High power view. Strong reaction deposits are present in the Golgi complex (G). Weak staining is present in the ER and nuclear envelope. $\times 1,200$

Fig. 1c. Electron micrograph of a rat hepatocyte stained for albumin. Electron dense reaction products that indicate antigenic sites for albumin are present in the secretory apparatus that include the ER, nuclear envelope (NE) and Golgi complexes (Golgi) and are accompanied by secretion granules, but not in the case of such cell organelles as peroxisomes (P), mitochondria and the nucleus. Staining intensity increases from the ER to the Golgi complex. Bar: $0.8 \mu \mathrm{m} . \times 15,900$

Figs. 2a, b. ER-rich regions of rat hepatocytes stained for albumin. Bar: $0.4 \mu \mathrm{m}$. Fig. 2a. Electron-dense reaction product in the cisternae of the rER and Golgi lamellae. The staining intensity varies in individual ER lamellae and is focussed within the ER. Numerous vesicles present around the Golgi complex are devoid of any reaction product. $\times 22,600$ Fig. 2 b. Reaction deposits are present in the cisterna of the rER and in some vesicles. Note the cisternae that are focally stained interspersed with negative cisternae (arrowheads). Some terminal dilatations contain lipoprotein particles (LP) and are negative for albumin. In contrast, terminal dilatations stained for albumin contain no lipoprotein particles (ALB). $\times 25,200$

Figs. 3a, b, c. Golgi apparatus of rat hepatocytes stained for albumin. Bar: $0.4 \mu \mathrm{m}$. Fig. 3a. The reaction product that indicates the sites of albumin is present in the Golgi lamellae from cis to trans and in secretion granules on the trans side. The peroxisome $(\mathrm{P})$ is devoid of the reaction product. $\times 49,200$ Fig. 3 b. Three lamellae on the cis side are weakly stained for albumin, but their peripheral dilatations are heavily stained. The innermost lamella is most heavily stained. On the trans side, tubulovesicular structures and secretion granules are positive but not reaction product is present in the lysosome (LYS). Some vesicles and the rER (ER) also are stained for albumin. $\times 39,600$ Fig. 3c. Two Golgi lamellae are interconnected by rigid lamella (RL) that is heavily stained for albumin. Other lamellae also are strongly positive. On the trans side, a positive vesicle fuses with a negative vesicular structure (arrowheads). $\times 45,800$

Figs. 4a, b, c. Golgi apparatuses of rat hepatocytes stained for albumin. Bar: $0.2 \mu \mathrm{m}$. Fig. 4a. On the cis side, tubulovesicular elements of the sER (SER) are stained (ALB) and appear to be in direct continuity with the rER (RER). Lipoprotein particles are present in the albumin-negative vesicles. On the trans side, some vesicles are positive for albumin. Note the two types of secretion granules; one negative for albumin but containing lipoprotein particles (LP), and the other contains both proteins. $\times 59,100$ Fig. 4b. Albumin (ALB) and lipoprotein particles are present in the peripheral dilatations of the same Golgi lamella that is sectioned tangentially (arrowheads), which demonstrates that both proteins are mixed in the Golgi lamellae. $\times 31,200$ Fig. 4c. A smoothsurfaced membrane structure extending from the transmost region of the Golgi complex stained for albumin. It is fusing with a transport vesicle containing albumin (arrowheads). $\times 54,400$

Figs. 5a-d. Serial sections of a Golgi complex after immunostaining for albumin. There is no direct connection between the ER (ER) and the Golgi lamellae or the tubulovesicular structures on the trans side. Note that transport vesicles with and without albumin, disappear in the next section, in which new vesicles appear at adjacent sites. Bar: $0.4 \mu \mathrm{m} . \times 27,900$

Figs. 5e, f. Sinusoidal sides of rat hepatocytes stained for albumin. Fig. 5e. Reaction deposits for albumin are present in the rER (ER) and in secretion granules (SEC GR) that are not open to the outer side of the cell. Bar: $0.4 \mu \mathrm{m}$. $\times 43,200$. Fig. 5 f. Two positive secretion granules (SEC GR); one is open to the outside (*). Bar: $0.4 \mu \mathrm{m} . \times 41,200$ 
on the trans side (Fig. 5a-d); this was independent of the presence or absence of albumin. In addition, small protrusions from Golgi elements that were seen on one section were absent from the next section of the series but new protrusions appeared in other portions. This suggests that these protrusions resulted from the fusion or fission of transport vesicles with Golgi elements. Furthermore, some secretion granules on the trans side were interconnected through fine tubules that had a diameter that were less than the thickness of the serial sections; therefore, there was interconnection of the secretion granules in one section but not in the corresponding portion of the next section.

\section{DISCUSSION}

The poor penetration of labeled antibody into sections is an inevitable problems of pre-embedding immunocytochemistry. Although many attempts have been made to solve this problem, no really good techniques have been established. We have developed a modified technique that uses mild fixation and a mild detergent (Triton WR-1339), with which to determine in detail the intracellular transport of secretory proteins.

We previously reported that there is segmental staining for albumin in the rER (56), and in study reported here we found it once again (Fig. 2). After mild treatment of the fixed sections with Triton X-100, diffuse albumin staining remained in segments of the cisterna of the rER. In addition, many of the smooth terminal dilatations of the rER and small vesicles in the cytoplasm (especially around the Golgi complex) contained no reaction deposits (Figs. 2, 3). Even with the excess permeation produced by Triton WR-1339, these structures remained negative, whereas the positive vesicles and dilatations showed the diffusion of albumin. Therefore, we believe that the segmental staining in the rER and the selective staining in the vesicles are not artifacts; they represent the actual localization pattern of albumin in these organelles.

The localization pattern of albumin in the rER has been reported for ultracryosections stained for albumin $(5,32)$. This pattern suggests that newly synthesized albumin molecules still bind to the rER membrane after vectorial discharge, whereas albumin-negative segments are occupied by proteins other than albumin and that the rER membrane regions bound to the albumin molecules can move laterally to other parts of the ER and form transitional elements. The latter are located not only in the area facing the cis side of the Golgi complex (28), but in other areas such as the terminal dilatations. If the lipid flow known in the cell membranes (6) also occurs in the ER membrane, then this movement of albumin molecules to the transitional elements might be compared to the formation of coated pits in the plasma membrane that takes place during receptor-mediated endocytosis on the cell surface $(18,41)$.

According to the evolutionary theory of the intracellular membrane system (4), the rER membrane can be compared with the plasma membrane. Therefore, lipid flow to a particular focus, such as the coated pits, also should take place for the rER membrane. If so, the formation of transitional vesicles could be mediated by a binding factor (probably a receptor) for albumin that is localized on the luminal surface of the rER membrane (24). This would function as the first condensing process for albumin in the secretory pathway because it is generally accepted that the coated pits act as a molecular filter, selecting some proteins and excluding others (7).

If newly synthesized proteins could move freely by diffusion within the lumen of 
the rER to the transitional elements, the condensing process would be restricted to the Golgi complex and the secretion granules; but the transport vesicles were stained more strong than the rER (having a staining intensity similar to that of the Golgi elements) which suggests the actual condensation of albumin in these vesicles. Furthermore, transport vesicles that contained lipoprotein particles were always negative for albumin (Figs. 2, 3, 4), evidence that albumin is not intermixed with the other secretory proteins, - at least, not with the lipoprotein particles in the intracellular pathway between the rER and Golgi complex. This is supported by the fact that there were many negative transport vesicles in addition to lipoprotein-containing particles around the Golgi complex (Figs. 2, 3, 4). After mild permeation with Triton WR1339, no increase in the number of positive vesicles was found; therefore, selective staining of the transport vesicles is not produced by false negative staining produced by inadequate permeation. Because hepatocytes simultaneously synthesize many other secretory proteins (such as $a_{1}$-antitrypsin, fibrinogen, apolipoproteins), it is indeed possible that the negative vesicles contain these proteins. There are several reports on the double labeling of secretory proteins or of membrane proteins $(3,14,48,53)$; but, the co-existence of two or more different proteins in the same transport vesicles of liver parenchymal cells has not yet to be clearly shown.

We found many protrusions positive for albumin on the membranes of such Golgi elements as the saccules and vacuoles (Figs. 3, 4). Although these protrusions might reflect either fusion of transport vesicles with the Golgi membranes or of vesicles being pinched off from the membranes, it is more likely that the former (fusion) takes place because albumin-positive protrusions often were noted on membranes of vacuoles negative for albumin (Fig. 3c). Some of these buds also had a fuzzy coat (Fig. 3a). It is not clear whether this coat is related to the N-terminal polypeptide segment of proalbumin that is exposed on the outer surfaces of the ER membranes (55) or whether it consists of clathrin, a major protein of coated vesicles $(31,40)$, but it is very likely that this coat functions as a recognition system which permits the vesicles to fuse specifically with the Golgi membranes and selectively to transport secretory proteins $(13,24)$. Moreover, the transport vesicles appear to fuse both with the stacked cisternae on the cis side and with the vacuoles on the trans side, which suggests that there may be a bypass through which albumin is carried directly to the Golgi vacuoles, as described by Franz et al. (12).

Although structural continuity between the ER and the Golgi complex has been described in several publications $(8,34,37,38)$, it is very difficult to assess such continuity in two dimensional pictures. Serial sectioning combined with immunocytochemical staining is eminently suitable such an analysis. In the study reported here, we analyzed the relation between the Golgi complex and its neighboring organelles as seen in serial sections after immunocytochemical staining. There was no evidence of a true structural continuity between the Golgi complex and the ER on either the cis or the trans side of the Golgi apparatus. The ER membrane, whether positive or negative, had no direct continuity with the Golgi elements (Fig. 5). The structural discontinuity of these organelles reported by several investigators who also observed serial sections $(23,46)$, supports our results. This structural discontinuity strongly suggests that albumin is transported by vesicles that bud from the transitional elements.

It is noteworthy that many albumin positive vesicles are present around the Golgi complex (Fig. 3, 4) and that some show fusion with Golgi elements. In the Golgi 
complex, albumin is intermixed with other secretory proteins (at least with lipoproteins) because the terminal swellings of the stacked cisternae of the Golgi complex and the secretion granules contain lipoprotein particles that show up in negative relief in the heavily stained matrix (Fig. 3, 4, 5). Secretion granules were frequent in the cytoplasm near the plasma membrane on the sinusoidal surface, and their number increased markedly in the cytoplasm after the administration of colchcine (Yokota and Fahimi, in preparation). Thus, albumin appears to be transported in hepatocytes in a manner similar to that established for pancreatic exocrine cells $(28,39)$. But, the accumulation of secretion granules in the cytoplasm, which is seen in pancreatic acinar cells, does not take place with albumin in hepatocytes under normal conditions. Therefore, condensation of the secretion products must occur earlier, probably during the transport from the ER to the secretion granules. This probability is supported by the fact that the staining intensity, which reflects the concentration of albumin is greater in this direction.

In cells that accumulate cytochemically demonstrable secretory proteins such as parotid gland cells (21), eosinophilic leukocytes (2), and lacrimal gland cells (20), a less intense staining in the stacked cisterna of the Golgi complex than in the secretory granules, which is also surprisingly lower than in the cisterna of the ER, seems to be characteristic. This suggests that a different condensing process operates in hepatocytes than in the cells cited above. In hepatocytes, it should be noted that newly synthesized secretory proteins are not stored for long periods; they are secreted continuously. Therefore, it is probable that the condensing process in the hepatocyte differs from that in secretory cells which first accumulate then discharge their secretory products when there are suitable stimuli.

Acknowledgements. We thank Miss. G. Kramer for her technical assistance.

\section{REFERENCES}

1. Avrameas, S. and T. Ternynck. Peroxidase labelled antibody and Fab conjugates with enhanced intracellular penetration. Immunochemistry 8, 1175-1179, 1971

2. Bainton, D.F. and M.G. FARQuHaR. Segregation and packaging of granules enzymes in eosinophilic leukocytes. J. Cell Biol. 45, 54-73, 1970

3. Bendayan, M. Double immunocytochemical labeling applying the protein A-gold technique. J. Histochem. Cytochem. 30, 81-85, 1982

4. Blobel, G. Intracellular protein topogenesis. Proc. Natl. Acad. Sci. U.S.A. 77, 1496-1500, 1980

5. Brands, R., J.W. Slot and H.J. Geuze. Albumin localization in rat liver parenchymal cells. Eur. J. Cell Biol. 32, 99-107, 1983

6. Bretscher, M.S. Direct lipid flow in cell membranes. Nature (London) 260, 21-23, 1976

7. Bretscher, M.S., J.N. Thomson and B.M.F. Pearse. Coated pits act as molecular filters. Proc. Natl. Acad. Sci. U.S.A. 77, 4156-4159, 1980

8. Claude, A. Growth and differentiation of cytoplasmic membranes in the course of lipoprotein granules synthesis in the hepatic cell I. Elaboration of elements of Golgi complex. J. Cell Biol. 47, 745-766, 1970

9. Edward, K., B. Fleischer, H. Dryburgh, S. Fleischer and G. Schreiber. The distribution of albumin precursor protein and albumin in liver. Biochem. Biophys. Res. Commun. 72, 310318,1976

10. Farquhar, M.G. Trafic of products and membranes through the Golgi complex. In Transport of Macromolecules in Cellular Systems, ed. Silverstein, S.C., Dahlem Konferenzen, Berlin, pp. 341-362, 1978 
11. Farquhar, M.G. and G.E. Palade. The Golgi apparatus (complex)-(1954-1981)-from artifact to center stage. J. Cell Biol. 91, 77s-103s, 1981

12. Franz, C.P., E.M. Croze, J.D. Morré and G. Schreiber. Albumin secreted by rat liver bypasses Golgi apparatus cisternae. Biochim. Biophys. Acta 678, 395-402, 1981

13. Fries, E., L. Gustafsson and P.A. Peterson. Four secretory proteins synthesized by hepatocytes are transported from endoplasmic reticulum to Golgi complex at different rates. $E M B O$ J. 3, 147-152, 1984

14. Geuze, H.J., J.W. Slot, P.A. VAn der Ley and R.C.T. Scheffer. Use of colloidal gold particles in double-labeling immunoelectron microscopy of ultrathin frozen tissue sections. J. Cell Biol. 89, 653-665, 1981

15. Glaumann, $H$. Studies on the synthesis and transport of albumin in microsomal subfractions from rat liver. Biochim. Biophys. Acta 224, 206-218, 1970

16. Glaumann, H. Albumin secretory pathway in the hepatocytes. In Albumin Structure, Biogenesis, and Function, eds. Peters, T. and I. Sjoholm, Pergamon Press, Oxford, pp. 41-50, 1977

17. Glaumann, H. and J.L.E. Ericsson. Evidence for the participation of the Golgi apparatus in the intracellular transport of nascent albumin in the liver cell. J. Cell Biol. 47, 555-567, 1970

18. Goldstein, J.L., R.G.W. Anderson and M.S. Brown. Coated pits, coated vesicles, and receptor-mediated endocytosis. Nature (London) 279, 679-685, 1979

19. Graham, R.C., Jr. and M.J. KARNovSKy. The early stage of absorption of injected horseradish peroxidase in the proximal tubules of mouse kidney: Ultrastructural cytochemistry by a new technique. J. Histochem. Cytochem. 14, 291-302, 1966

20. HAND, A.R. and C. Oliver. Relationship between the Golgi apparatus, GERL, and secretory granules in acinar cells of the rat exorbital lacrimal gland. J. Cell Biol. 74, 399-413, 1977

21. Herzog, V. and F. Miller. Die Lokalization endogener Peroxydase in der Glandula parotis der Ratte. Z. Zellforsch. 107, 403-420, 1970

22. IKehaRA, Y., K. OdA and K. Kato. Conversion of proalbumin onto serum albumin in the secretory vesicles of rat liver. Biochem. Biophys. Res. Commun. 72, 319-325, 1976

23. Inoue, K. and K. Kurosumi. Cytochemical and three-dimensional studies on Golgi apparatus and GERL of rat anterior pituitary cells by transmission electron microscopy. Cell Struct. Funct. 2, 171-186,1977

24. JAMIESON, J.D. Intracellular transport and discharge of secretory proteins: Present status and future perspectives. In Transport of Macromolecules in Cellular Systems, ed. S.C. Silverstein, S.C., Dahlem Konferenzen, Berlin, pp. 273-287, 1978

25. JAMIESON, J.D. and E.G. PALADE. Intracellular transport of secretory proteins in the pancreatic exocrine cell I. Role of the peripheral elements of the Golgi complex. J. Cell Biol. 34, 577-596, 1967

26. JAMIESON, J.D. and G.E. PALADE. Intracellular transport of secretory proteins in the pancreatic exocrine cell II. Transport to condensing vacuoles an zymogen granules. J. Cell Biol. 34, 597615,1967

27. JAmieson, J.D. and G.E. Palade. Synthesis, intracellular transport, and discharge of secretory proteins in stimulated pancreatic exocrine cells. J. Cell Biol. 50, 135-158, 1971

28. Jamieson, J.D. and G.E. Palade. Production of secretory proteins in animal cells. In International Cell Biology, eds. Brinkley, B.R. and K.R. Portor, The Rockfeller University Press, New York, pp. 308-317, 1977

29. Judah, J.D., M. Gamble and H.J. Steadman. Biosynthesis of serum albumin in rat liver. Evidence for the existence of 'proalbumin'. Biochem. J. 134, 1083-1091, 1973

30. Judah, J.D. and P.S. QuINN. On the biosynthesis of serum albumin. Trends Biochem. Sci. 1, 107-109, 1976

31. Keen, J.H., M.C. Willingham and I. Pastan. Clathrin and coated vesicle proteins. Immunological characterization. J. Biol. Chem. 256, 2538-2544, 1981

32. Keller, G.-A., K.T. Tokuyasu, A.H. Dutton and S.J. Singer. An improved procedure for immunoelectron microscopy: Ultrathin plastic embedding of immunolabeled ultrathin frozen sections. Proc. Natl. Acad. Sci. U.S.A. 81, 5744-5747, 1984

33. MoRRÉ, D.J. An alternative pathway for secretion of lipoprotein particles in rat liver. Eur. 
J. Cell Biol. 26, 21-25, 1981

34. Morré, D.J. and L. Ovtracht. Structure of rat liver Golgi apparatus: Relationship to lipoprotein secretion. J. Ultrastruct. Res. 74, 284-295, 1981

35. Morgan, E.H. and T., Jr. Peters. The biosynthesis of rat serum albumin V. Effect of protein depletion and refeeding on albumin and transferrin synthesis. J. Biol. Chem. 246, 3500-3507, 1971

36. Newmark, P. Pathway to secretion. Nature (London) 281, 629-630, 1979

37. Novikoff, A.B. and P.M. Novikoff. Cytochemical contribution to differentiating GERL from the Golgi apparatus. Histochem. J. 9, 525-551, 1977

38. Ovtracht, L., D.J. Morré, R.D. Cheetham and H.H. Mollenhauer. Subfractonation of Golgi apparatus from rat liver: Method and morphology. J. Microscopie 18, 87-102, 1973

39. PAlADE, G.E. Intracellular aspects of the process of protein synthesis. Science (Wash. D.C.) 189, 347-358, 1975

40. Pearse, B. Clathrin: A unique protein associated with intracellular transfer of membrane by coated vesicles. Proc. Natl. Acad. Sci. U.S.A. 73, 1225-1259, 1976

41. Pearse, B. Coated vesicles. Trends Biochem. Sci. 5, 131-134, 1980

42. Peters, T., Jr. The biosynthesis of rat serum albumin I. Properties of rat albumin and its occurrence in liver cell fractions. J. Biol. Chem. 237, 1181-1185, 1962

43. Peters, T., Jr. Serum albumin. In The Plasma Proteins. Structure, Function, and Genetic Control I, ed. Putnam, F.W., Acad. Press, New York, pp. 133-181, 1975

44. Peters, T., Jr., B. Fleischer and S. Fleischer. The biosynthesis of rat serum albumin IV. Apparent passage of albumin through the Golgi apparatus during secretion. J. Biol. Chem. 246, 240-244, 1971

45. PORTER, R.P. The hydrolysis of rabbit $\gamma$-globulin and antibodies with crystalline papain. Biochem. J. 73, 119-126, 1959

46. Rambourg, A., Y. Clermont and L. Hermo. Three-dimensional architecture of the Golgi apparatus in Sertoli cells of rat. Am. J. Anat. 154, 455-476, 1979

47. Redman, J.E. and G. Cherian. The secretory pathway of rat serum glycoproteins and albumin. Localization of newly formed proteins within the endoplasmic reticulum. J. Cell Biol. 52, 231-245, 1972

48. Rотн, J. The preparation of protein A-gold complexes with $3 \mathrm{~nm}$ and $15 \mathrm{~nm}$ gold particles and their use in labelling multiple antigens on ultra-thin sections. Histochem. J. 14, 791-801, 1982

49. Rothman, J.E. The Golgi apparatus: Two organelles in tandem. Science (Wash. D.C.), 213, 1212-1219, 1981

50. RusSell, J.H. and D.M. Geller. Rat serum albumin biosynthesis: Evidence for a precursor. Biochem. Biophys. Res. Commun. 55, 239-245, 1973

51. Schreiber, G. and J. Urban. The synthesis and secretion of albumin. Rev. Physiol. Biochem. Pharmacol. 82, 28-95, 1978

52. Straus, A.W., C.D. Bennett, A.M. Donohue, J.A. Rodkey and A.W. Alberts. Rat liver pre-proalbumin: Complete amino acid sequence. J. Biol. Chem. 252, 6846-6855, 1977

53. Strous, G.J.A.M., R. Willemsen, P. van Kerkhof, J.W. Slot, H.J. Geuze and H.F. Lodish. Vesicular stomatitis virus glycoprotein, albumin, and transferrin are transported to the cell surface via the same Golgi vesicles. J. Cell Biol. 97, 1815-1822, 1983

54. Tartakoff, A.M. The Golgi complex: Crossroads for vesicular trafic. Int. Rev. Exp. Pathol. 22, 227-251, 1980

55. Vlasuk, G.P., J. Ghrayeb and F.G., Jr. Walz. Proalbumin is bound to the membrane of rat liver smooth microsomes. Biochem. Biophys. Res. Commun. 94, 366-372, 1980

56. Yokota, S. and H.D. FAнimi. Immunocytochemical localization of albumin in the secretory apparatus of rat liver parenchymal cells. Proc. Natl. Acad. Sci. U.S.A. 78, 4970-4974, 1981 